\title{
Men's artistic gymnastics: \\ is the use of elastic surfaces systematic in the training process?
}

CDD. 20.ed. 796.41

http://dx.doi.org/10.1590/1807-55092016000100051
Marco Antonio Coelho BORTOLETO*

Tiago Furtado COELHO*
*Faculdade de Educação Física, Universidade Estadual de Campinas, Campinas, SP, Brasil.

\begin{abstract}
In Artistic Gymnastics, the area (the apparatus) represents the most relevant systemic component. Thus, when one strives to comprehend the internal logic of this sport, the gymnast-apparatus relationship warrants special attention. A change in the training paradigm was observed, showing that the use of Elastic Surfaces (ES) is an essential resource, due to the contemporary features of this sport, such as the hyper-valorisation of acrobatics and a greater presence of flight elements. Through a case study developed in a men's artistic gymnastics high-performance gymnasium, this study analysed the use of different ES in the training process. Although coaches recognize the importance of ES in training programs, the record of daily activities showed that this use is still limited to select equipment and is not systematic. Such difficulties are due mainly to the lack of educational programs to the development of certain specific methodologies and the non-existence of national equipment suppliers certified by International Gymnastics Federation.
\end{abstract}

KEY WoRDS: Sports training; Competitive gymnastics; Sporting technology; Elastic equipment.

\section{Introduction}

Artistic Gymnastics (AG) from a systemic point of view should be considered a dynamic/open system, and therefore receptive to outside interferences when searching for its equilibrium ${ }^{1}$. The systemic analysis of AG's internal logic reveals an individual practice (psychomotor) developed in a standard space ("the apparatus"), manifesting encoded skills $s^{2-3}$. Thus, space becomes the main element of the praxeological system, deserving a detailed analysis 4 .

Considering that $\mathrm{AG}$ is a secular sport, present at the modern Olympic Games since the first edition in 1896, its sociocultural context is considered traditional making the modernization of the sport slower $^{3,5}$. Nevertheless, it was in the practice space, meaning in the apparatus, that the most significant changes were noted ${ }^{6}$.

In the 1980's, in Men's Artistic Gymnastics (MAG), a significant change in material and technology was noticed, which together revealed a paradigm modification the substitution of the rigid apparatus with the flexible (elastic) ones. These changes were, in great measure, influenced by the Code of Points
(COP) guidelines, which led to the hyper-valorisation of acrobatics and flight elements, and consequently, to even more complex and dynamic competitive routines. One of the consequences of being gradually higher is the higher impact of landings, for example ${ }^{7}$.

As a consequence of these apparatus changes, a great transformation was observed in training practices and in routines performed in competitions, transformations which significantly modified the gymnasts' technical and physical preparation ${ }^{3,7}$. This new generation of equipment and Elastic Surfaces (ES) modified, among other things, the execution time of acrobatic elements, requiring less power and, consequently, needing less energy ${ }^{8-9}$.

If we consider repetition as a fundamental characteristic of AG (both MAG and WAG), either in learning and mastering specific skills, the correct use of ES has considerably contributed to the reduction of impact/stress on body joints ${ }^{10}$, to the increase of safety ${ }^{11}$, and, therefore, to the reduction of injuries, especially to knees, shoulders and ankles ${ }^{12-13}$. In other words: 
Investigations of elastic sport surfaces have included gymnastics spring-floors, running tracks, gymnasium floors, and others (Greene \& McMahon, 1979; McMahon \& Greene, 1978, 1979; Nigg, Yeadon, \& Herzog, 1988). Although the initial idea for the spring-floor involved a desire for enhanced safety through reduced landing impact "harshness" (Arampatzis, Bruggemann, \& Klapsing, 2000; Nigg, Luethi, Denoth, \& Stacoff, 1983; Wilson et al., 1986), the evolution of the gymnastics spring-floor has led to increased elastic behavior with corresponding increases in tumbling height and skill difficulty (Holvoet, Lacouture, \& Duboy, 1999; McNeal, Sands, \& Shultz, 2007; Paine, 1998) ${ }^{9}$ (p.32).

As an example, we observed that in the first decades of the 20th century, Floor Exercises (FX) were performed outdoors, on natural grass, beaten earth or even on thin layers of sawdust. They were gradually transferred to artificial surfaces, at first made of "tatami" (straw plates covered with a canvas), then from cotton-filled fabric mats and, finally, from synthetic foam mats (with even more sophisticated materials, densities, forms and sizes) ${ }^{14}$. It was in the 1980s that the "Spring Floor" system, composed of springs, wooden boards, an agglomerated polyurethane foam covered with a thick carpet, modifying the FX routines significantly ${ }^{6,9}$.

This technological advance ultimately reveals the search for surfaces/equipment with a greater reactive capacity, that is, for an apparatus capable of responding to the pressure exerted through speed or lifting of the Center of Mass (CM) of the gymnast and, at the same time, with a higher capacity to absorb impact energy ${ }^{15}$.

The Horizontal Bar (HB) developed by NicholsKetchum in $1998^{a}$, for example, brought a new steel composition and a dynamic anchoring system, which contributed to the development of elements with an aerial phase (or "flight elements") such as Markelov, Kovacs, Kolman, Gaylord, and also dismounts with double straight somersault with a double twist or until triple somersault ${ }^{16}$.

In the same manner, the other MAG apparatus (Parallel Bars, Rings, Vaulting Table and Pommel Horse), as well as other complementary equipment used in training, underwent major modifications in their architecture and the materials used for their elaboration.

In Vault (VT) routines, a technological improvement of the trampoline (Reuther model) in the 1980's and the substitution of the "horse" (rigid surface) for the "Pegasus" table model (with elastic/more flexible components) in $2002^{6}$ generated a considerable repulsion (upper limbs), a higher elevation of the gymnast CM during the second phase of the flight (post flight. Thus resulting in greater height and more time to accomplish rotations during the vault. The Yurchenko Group's (EG III) vault development, incorporated into the COP in 1983, reinforces this thesis ${ }^{17}$.

In the Parallel Bars (PB), the flight elements, such as Belle, Morisue, Lee Chul Hon/Sasaki and Suarez, became more frequent, as more flexible bars made from glass fiber/carbon coating with wooden blades allowed the development of techniques that protect the gymnast CM right over the bars.

In all MAG apparatus, the best technology of mats used for landing, in addition to improving the surface stability, have allowed greater absorption of impact energy, generating significant modifications in the landing techniques and permitting dismount elements with more rotations ${ }^{18-19}$.

The patents displayed in TABLE 1, from the 1970 s onwards, represent some examples of this technological development, having practical consequences starting in the 1980 's ${ }^{11,20-21}$. It is worth noting that this process required the testing, regulation and subsequent certification by FIG for all apparatus, in conformity with the Code of Points, General Regulations and, mainly by the Apparatus Norms $s^{3,22}$. 
TABLE 1 - Elastic equipment/technology patents for AG.

\begin{tabular}{llc}
\hline Title & \multicolumn{1}{c}{ Patent } & Date \\
\hline Roll-fold floor mat for gymnastic and athletic purposes & US Patent 3636576 & 1972 \\
Resilient floor, especially for gymnasiums & US Patent 3828503 A & 1973 \\
Arrangement for Floor Gymnastics/Floor Panel System & US Patent 4135755 & 1977 \\
Gymnastic floor structure having vertical elasticity & US Patent 4648592 & 1985 \\
Gymnastic apparatus for performing vaulting exercises & European Patent EP 0885634A2 & 1997 \\
Gymnastics springboard with adjustable elasticity & European Patent EP 7175567 & 2003 \\
designed for training and competition & Germany Patent DE 2103315 A1 & 2007 \\
Gymnastic floor structure & US Patent 7849646 B2 & 2007 \\
Air-cushion floor & China Patent CN 201099969 Y & 2011 \\
Flexible mat with multiple foam layers & US Patent 20130017372 A1 & \\
\hline
\end{tabular}

Because of these technological advancements, some acrobatic elements, unexpected a short while ago, have become common. These elements are often presented alongside others, allowing the execution of acrobatic sequences of higher complexity with precision and safety, as seen in the Japanese gymnast Kohei Uchimura's (FIGURE 1) in the first three tumble passes of his FX in the World Championship in Tokyo, 2011.

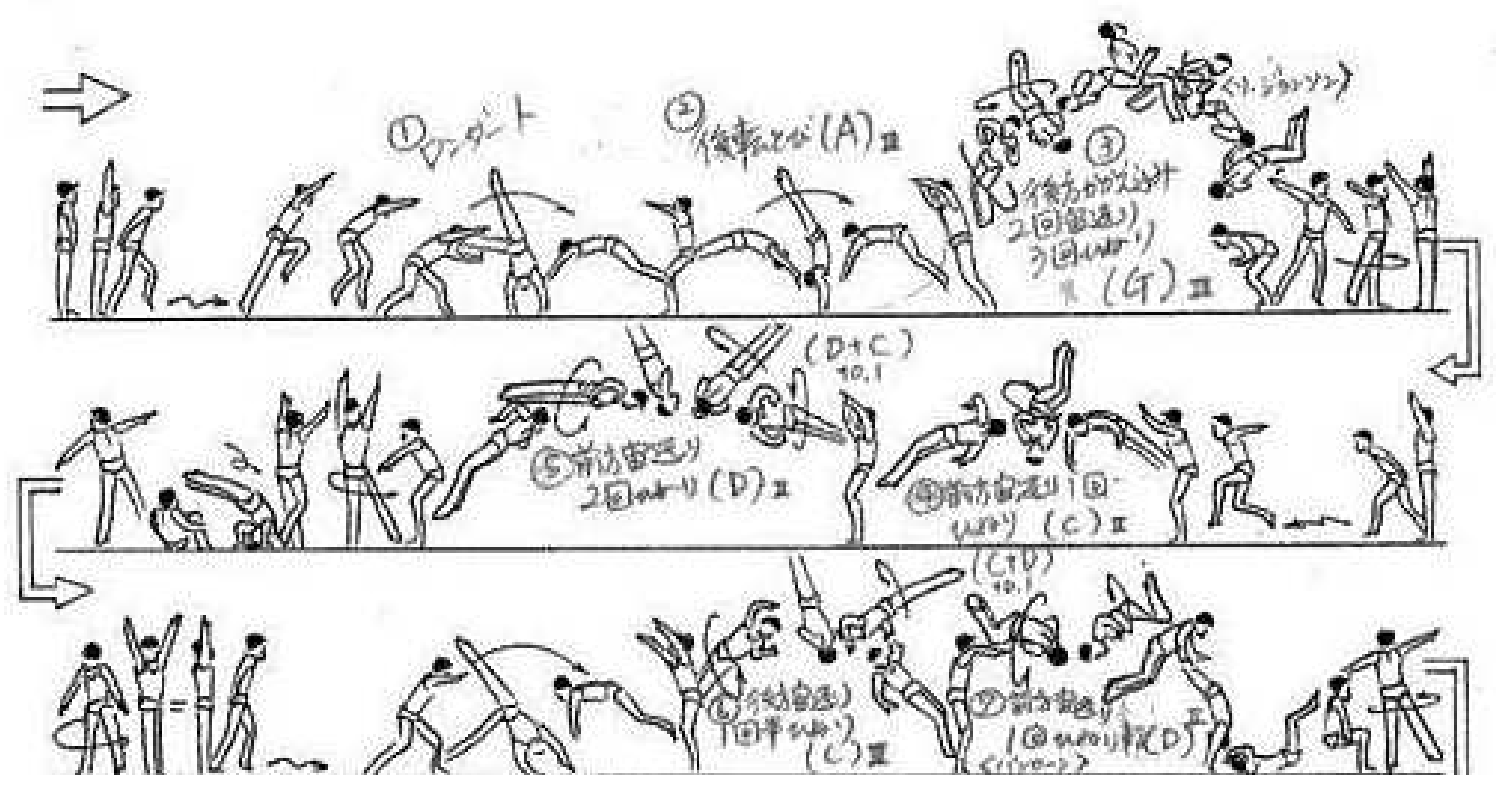

FIGURE 1 - Kohei Uchimura's Floor Exercise.

By examining the catalogues of the main manufactures of AG equipment, as well as the activities conducted in high-performance gymnastics training centers ${ }^{3}$, we can observe a great variety of ES (trampoline, fast-track, tumble track, pit foam, mats), equipment that has become essential for the development of contemporary MAG.

In this context, the present article analyses the use of Elastic Surfaces (ES) during the training process of highperformance in one of Brazil's main MAG gymnasiums. 


\section{Method}

The field research was conducted in a MAG club in the state of São Paulo (Brazil), with high level gymnasts (national and international champions), whose competition results over the last ten years placed the gymnasium within the best nationwide.

The observations took place over a period of nine months (2013-2014), with 25 sessions (approximately 175 hours of direct observation), adapting the visits to the gym's training and competition schedule. The study had the prior authorization of the head coach and from those responsible for the institution.

It is worth noting that, although female gymnasts trained in the same gym on a daily basis, the activities of these gymnasts were not analyzed.

The data were collected using two instruments: direct observation, duly registered in a "field diary" (notebook), following the model proposed by LUDKE and ANDRÉ É $^{33}$ adapted by BORTOLETO ${ }^{3}$; and semi-structured interviews which were conducted with the three MAG coaches, following the guidelines proposed by SEverino ${ }^{24}$. It is worth noting that, in the opinion of Triviños ${ }^{25}$, this approach " $[\ldots]$ at the same time that it values the presence of the investigator, it offers all possible perspectives for the informant to reach the necessary freedom and spontaneity, thus enriching the investigation" (p.146).

As an inclusion criteria, the interviewee had to be acting officially as a coach for over a year at the institution and, as exclusion criteria, they could not

\section{Results}

The gymnasts practiced from Monday through Friday in two periods (morning and afternoon) and on Saturday mornings, divided into the following age groups (categories): ages 9-10, ages 11-12, ages 13-15 (junior) and age 16+ (adult or senior). This is one of the few clubs in Brazil that has gymnasts in each one of the official age groups, many of whom are participants of the national teams. The junior and senior gymnasts have had experience in international championships, including, in some cases, World Championships and the Olympic Games, in which the adults were five-times champions and twice second-place in the last eight editions. These data confirm that this is a high-performance gym, nationally renowned in this modality. be under license or in an irregular work situation for any reason.

The data obtained underwent a thematic and interpretive analysis ${ }^{24}$, through which the collected data were reduced through a system of categories elaborated in accordance with the objectives proposed in this study. Thus, a qualitative analysis of the data was conducted by tabulating the categories as suggested by SouzA Junior et al. ${ }^{26}$ for a categorical thematic analysis. At last, the Content Analysis was utilized as an organizational and data reduction methodology ${ }^{27}$, a procedure understood to be "like a set of techniques for communication analysis, which uses systematic and objective procedures for content description of messages"27 (p.38).

Since the field study was conducted during the gym's regular activities, data collection needed to be adjusted to the training context ${ }^{3}$, considering the club's official calendar. For this reason, some observations were cancelled or had their dates changed for reasons such as: competition, festivities, trips and other commitments, which kept the athletes out of the gym. The first ten observation sessions map the training sessions of all the gymnasts who attended the gym (a panoramic vision). In the second phase, over a period of 15 sessions, the specific activities that used the ES available in the gym were analysed.

The research was approved by the Research Ethics Committee of the Faculty of Medical Sciences of the University of Campinas (UNICAMP).

The coaches have between 10-20 years of experience, including international camps and competitions, and the most experienced of them is one of the coaches of the Brazilian Senior National Team.

Although it is one of the leading gyms in Brazil, with all the official MAG apparatus (all imported), in the category of ES, it only has one Trampoline (TRA), an acrobatic track known as Tumble Track (TT), as well as three additional official apparatus installed on the pit foam - an insufficient structure compared to those available in renowned gyms in the international scene.

In general, the use of the ES represents a small part of the time dedicated to training, around 40 minutes daily, considering both training sessions 
(morning and afternoon). This timeline may vary depending on the training period and that amount may be even reduced during pre-competitive periods, for instance. In the first three age groups, its use is more frequent and regular than the seniors (C3), given that the senior gymnasts practice more on the official apparatus.

Gymnasts who are treating injuries, especially on the superior limbs, who could not use the apparatus, would have a greater use of the ES, trying not to completely interrupt their activities and maintaining them "active" 28 in the gymnasium (integrated with the group and the training routine).

The pit foam, in particular, is frequently utilized during technical training, given that coaches prefer to use the apparatus over it, since it offers greater safety. Coach 1's discourse reveals the general opinion regarding the use of the ES:

I believe the elastic surfaces are really very important, indispensable today, something that was noticed abroad a long time ago, but not here in Brazil. In the US, you won't find a gym without at least one tumble track, 4 or 5 elastic beds and all the apparatus geared towards the pit. Over there, children learn almost naturally, because they play a lot, gaining a huge notion of space. Afterwards, transferring that to the official apparatus is very simple (C1).

Among the acrobatic elements within the MAG $\mathrm{COP}^{29}$, the use of ES for the purpose of teaching and or improvement that we most frequently observed were the following:

TABLE 2 - Gymnastic/acrobatic elements trained on ES.

\begin{tabular}{|c|c|c|}
\hline Elements & Apparatus & ES \\
\hline Cross, Unlock, dismounts (somersaults). & Rings (SR) & TRA \\
\hline $\begin{array}{l}\text { Sequence of backward somersaults; Tempo; Sequences of forward somersaults; } \\
\text { Cartwheel, Round off, Flic-Flac/Backward Handspring. }\end{array}$ & Floor (FX) & TT \\
\hline Pirouette (rotations in longitudinal axis); Somersaults (simple; double). & $\begin{array}{l}\text { All apparatus } \\
\text { (except Pommel Horse) }\end{array}$ & TRA, TT \\
\hline $\begin{array}{l}\text { Front Handspring Vault, Round off, Flic-Flac/Backward Handspring, } \\
\text { Yurchenko, Triple forward somersault. }\end{array}$ & Vaulting (VT) & TT \\
\hline Suarez, Somersaults inside the bars, Diamidov, Carballo, Belle. & Parallel Bars (PB) & TRA \\
\hline Yamawaki, Tkatchev, Kovacs, Giant, Jäger, Gaylord, Endo/Stalder (upswing). & Horizontal Bar (HB) & TTA \\
\hline
\end{tabular}

\section{Discussion}

Although coaches recognize the importance of using the ES for the preparation of gymnasts, its systematic use (quantified and temporalized) is still difficult due to the scarcity of equipment, their inferior quality and, mainly, by the lack of habit of its use. This contradiction can be noted in the discourse of the coaches:

I believe that using the elastic surface helps to increase the gymnast's longevity, to consider to reduce the rate of injuries and to increase the number of repetitions with less effort. When the gymnast is very tired, the technique suffers and when you have the elastic surface, you can repeat it many times, with less effort, leaving the gymnast less tired and allowing him to pay more attention to the technique. So, the elastic surfaces are surely beneficial (C2).
In our gym, we don't work with elastic surfaces very much, I think we can work with them more. The younger gymnasts train more in the elastic equipment (track, elastic bed), and that helps a lot. In the future, you will see the difference, because a gymnast who has greater spatial command can better perform elements that are more difficult. If he doesn't learn an element, he shifts to another easier one. I think we could use the ES more (C3).

The coaches confirm that the use of the ES contributes to the transfer ${ }^{11}$ of the learning of different skills, for example, in the back somersaults performed on the TRA, and learning the Kovacs elements and its variations (among them, the Kolman), currently very common in the HB routines. In the words of $\mathrm{C} 2$ : 
There's an exercise that we call "kabum" - hitting your back and then throwing your ankles to make a countermovement. Many exercises, as like, the Diamidov for the Parallel Bars are trained this way. There's also the "Codis", which is falling belly down and executing a somersault, a very common exercise for training the Tsukahara or the Kovacs, both on the Horizontal Bar. In the United States, they train Kovacs sequences on the trampoline with an absurd perfection and then transfer to the Horizontal Bar with a high rate of success. The Tkatchev on the Horizontal Bar is also taught with exercises on the Track or on the Trampoline.

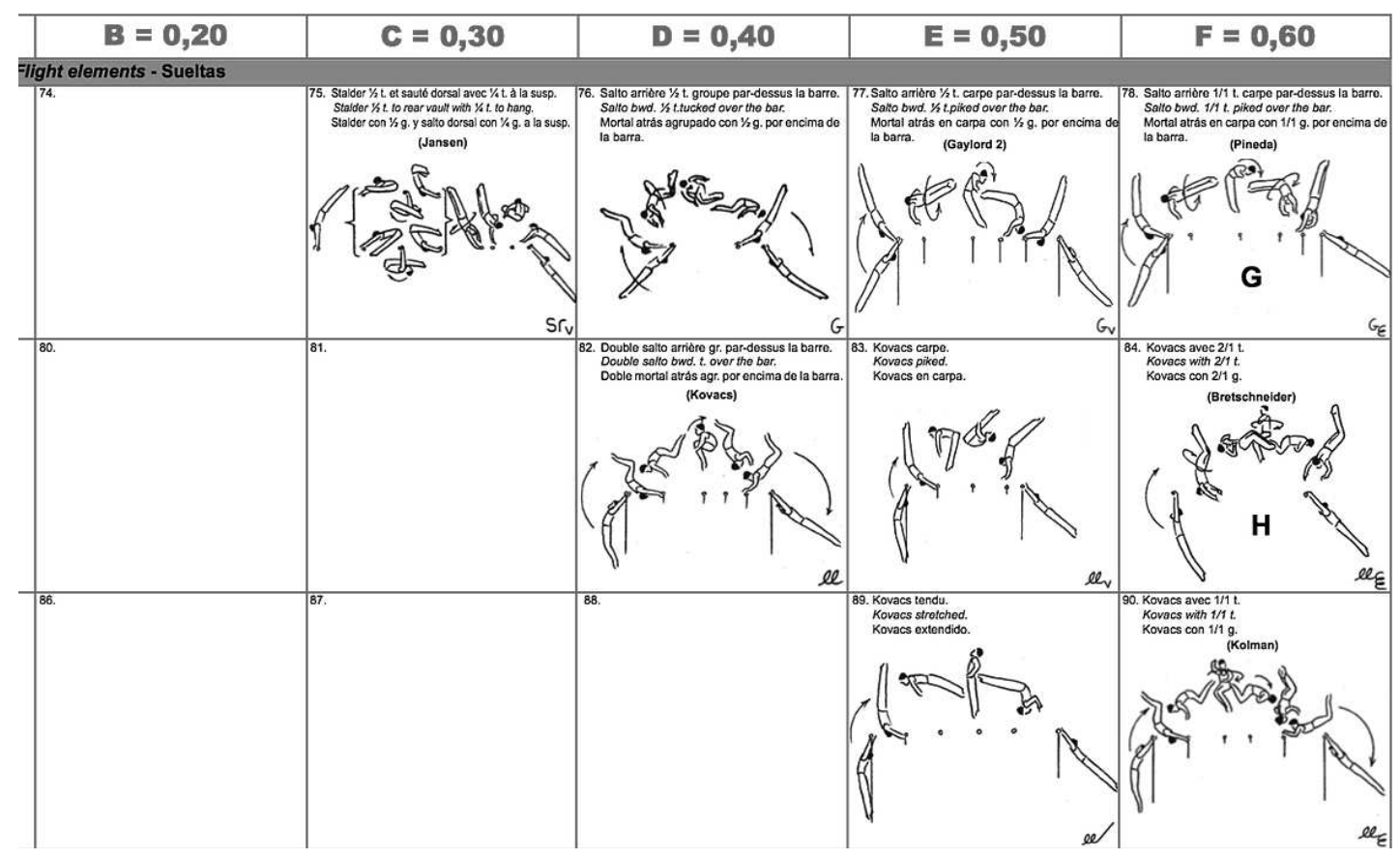

FIGURE 2 - MAG COP 22 - Kovacs and its variations on the HB.

The TT is used almost daily for training acrobatic sequences - tumbling (Round Off - Backward Handspring - Back Somersault; Forward Handspring - Front Somersault; Front Somersault - Front Somersault Full Twist, among others) significantly increasing the number of repetitions completed. When one compares the acrobatic sequences completed on the floor with those on the TT, one clearly notices that, on the TT, a greater height is achieved in acrobatics, with less impact, and less demand of power from the lower limbs, making learning as well as improvement easier (C1). In fact, Coach 3 stated that: "[...] we use the Tumble Track more than the Trampoline, because it better simulates the Floor, greatly improving the acrobatic elements training". Coach 1's opinion helps to understand this process:

I frequently use the Tumble Track. To learn a new element, you use the track first and then go to the Floor. When the gymnast has some injury (in the wrist, for example), I mostly use the track, and when I notice they're too tired to use the Floor, we use the Trampoline (C1).
On the other hand, to train high difficult acrobatic elements, like dismounts in double somersault, the TRA is used on a more frequent basis, corroborating Turoff's ${ }^{11}$ position (p.2389). An example that was observed repeatedly was the element Suarez of the PB, executed at first on the TRA in order to master the activity and subsequently, reproduced on the apparatus itself. Coach 3 confirms stating: "It is possible to work $50 \%$ of the Parallel Bars elements and almost all the elements of the Horizontal Bar on the Trampoline, and then transfer to the apparatus".

In addition, using the TT is also common for the general physical preparation of gymnasts, with the execution of exercise sequences (vertical jumps, somersaults sequences (tucked; piked; stretched), hands repulsion off, cartwheels, round offs, forward and backward handspring, reverse vaults, etc.). The use of the TT is not more common because this equipment is not installed at ground level, increasing the risk for acrobatic training added the Coach 3. 
Another recreational use for the ES was observed, allowing gymnasts "to play" during or at the end of training sessions particularly during noncompetitive periods. Although they have been rare, these activities proved to be an interesting ludic option, in the middle of the strict and rigorous training system, typical of high-performance ${ }^{3}$.

MAG has shown a tendency to value acrobatic and flight elements increasingly using aerial space and making more "spectacular" routines, adjusting to the model of spectacular sports. A move towards more dynamic exercises can be observed, with the exception of the pommel horse, according to the sporting development logic reported by VIGARELLo ${ }^{5}$ in the 1980 's.

Technological development, in particular of the ES, can be viewed as a response to this tendency, noticeably modifying MAG's training system ${ }^{21}$. As mentioned above, the ES are already a part of the dayto-day of the main AG high-performance training centers ${ }^{9}$. Nevertheless, the reality of the gym analyzed in this study shows the challenge for Brazilian clubs to follow this tendency, very likely due to the difficulty of importing the equipment, given that Brazilianmade materials have not been approved by FIG for not offering the same quality. This delay does not permit Brazilian clubs to follow the international tendency, as stressed by the discourse of the coaches: MAG has changed in many ways. The Horizontal Bar used to be rigid and today it is flexible so that it launches/bounce the gymnast. The improvement in the material assisted in the increase of the technical level; gymnasts today perform more difficult elements than in the past. Today, the amount of movements is greater some competitions have ten difficult elements - so the elastic surfaces have permitted the increase of training volume. In short, the elastic equipment (mats, trampoline, etc.) has improved greatly, and we need to accompany this (C3).
I think we lack the tradition of the use of elastic surfaces, which makes it challenging for us to work with ES (C2).

It seems clear that the difficulty coaches' face in incorporating the use of ES in training can also be attributed to the nonexistence of continued education as mentioned by $\mathrm{C} 1$ and $\mathrm{C} 2$. For this reason, due to the lack of instruction in the use of $\mathrm{ES}$, this use depends on the knowledge acquired by coaches during visits, special trainings and other activities conducted in institutions abroad, as highlighted by $\mathrm{C} 2$ :

Last year, I was in Russia and noticed that they frequently use the Trampoline, the Tumble Track, and other elastic surfaces. Recently, the coach of the Russian National Team was here in our gymnasium and talked extensively about the elastic surfaces. I also recall that in the American National Congress of AG (USA) there are always two or three lectures on the use of the Trampoline or the Tumble Track for technical training.

Although this is a case study, in dealing with a nationally renowned gymnasium, it suggests that this situation may point to the reality in regards to the nation-wide difficulty in acquiring the ES (C3), and also to the non-existence of specific continuing education (C2) and, consequently, to the lack of systematic use of the ES (C1).

Therefore, we suggest clubs, state federations, should give greater attention and, mainly, by the Brazilian Gymnastics Federation, to the promotion of specific education program, as well as to encourage the national manufacture of ES with adequate quality for high-performance training. It is contradictory that a country that desires to become a world class international power in AG does not have national providers of approved apparatus by FIG and also ES training equipment, as Europe, USA, Japan, and Australia do.

\section{Note}

a. Patent registered in 1988: Nichols-Ketchum, M. Gymnastics bar and method of making the same. American Sports International, Ltd. (Jefferson, IA) US Patent 6,475,118. 


\section{Resumo}

Ginástica artística masculina: é sistemático o uso das superfícies elásticas no processo de treinamento?

Em alguns esportes, o espaço de jogo representa o componente sistêmico de maior relevância: esse é o caso da Ginástica Artística (GA). Desse modo, quando nos empenhamos em compreender a lógica interna dessa modalidade precisamos dedicar especial atenção à relação ginasta-aparelho. Observamos uma mudança no paradigma de treinamento em que o uso das Superfícies Elásticas constitui um componente essencial, visando atender às características contemporâneas desse esporte, como a hipervalorização das acrobacias e a maior presença dos elementos ginásticos com "fase aérea". Nessa oportunidade, analisamos, a partir de estudo de caso de um ginásio de treinamento de alto rendimento de Ginástica Artística Masculina, o emprego de diferentes Superfícies Elásticas (SpE) na preparação dos ginastas. Embora os treinadores reconheçam o papel fundamental das SpE para o desenvolvimento dos ginastas, seu uso cotidiano ainda é restrito a poucos equipamentos e realizado de modo assistemático. Essas dificuldades se devem principalmente à ausência de programas formativos que desenvolvam metodologias especificas e à inexistência de fornecedores de equipamentos nacionais com qualidade certificada pela Federação Internacional de Ginástica.

PalavRAS-ChaVE: Treinamento desportivo; Ginástica competitiva; Tecnologia esportiva; Equipamentos elásticos.

\section{References}

1. Bertalanffy LV. Teoria dos sistemas. Rio de Janeiro: Fundação Getúlio Vargas; 1976.

2. Parlebas P. Contribution à un lexique commenté en sciencie de l'action motrice. Paris: INSEP; 1981.

3. Bortoleto MAC. La lógica interna de la gimnasia artística masculina (GAM) y estudio etnográfico de un gimnasio de alto rendimiento [tese]. Lleida (ESP): Institut Nacional d'Educació Física de Catalunya, Universutat de Lleida; 2004.

4. Bortoleto MAC. A Ginástica artística estudada a partir da óptica da praxiologia motriz: reflexôes preliminares. In: Ribas JMF, organizador. Jogos e esportes: fundamentos e aplicaçôes da praxiologia. Santa Maria: UFSM; 2008. v.1, p.125-44.

5. Vigarello G. Une histoire culturelle du sport: techniques d'hier... et d'aujourd'hui. Paris: R. Laffont/Revue EPS; 1988.

6. Oliveira MS, Bortoleto MAC. Apontamentos sobre a evolução histórica, material e morfológica dos aparelhos da ginástica artística masculina. Rev Educ Fís/UEM. 2011;22:10-20.

7. Thomas L, Fiard J, Soulard C, Chautemps G. Gimnasia deportiva: de la escuela. . . a las asociaciones deportivas. Lérida: Agonos; 1997.

8. Smoleuskiy V, Gaverdouskiy I. Tratado general de gimnasia artística deportiva. Barcelona: Editorial Paidotribo; 1996.

9. Sands AW, Kimmel LW, Mcneal RJ et al. Kinematic and kinetic tumbling take-off comparisons of a spring-floor and an air floor: a pilot study. Sci Gymnastics J. 2013;5:31-46.

10. Arkaev L, Suchilin NG. Gymnastics: how to create champions; the theory and methodology of training top-class gymnasts. Oxford: Meyer \& Meyer; 2009.

11. Turoff F. Artistic gymnastics: a comprehensive guide to performance and teaching skills for beginners and advanced beginners. Dubuque: Brown; 1991.

12. Leglise M. Some medical observations on the development of high-level gymnastics. World Gymnastics. 1985;23:27.

13. Fink H. Some considerations for gymnastics conditioning. World Gymnastics. 1985;25:48.

14. Karacsony I, Cuk, I. Floor exercises: methods, ideas, curiosities, history. Ljubljana: University of Ljubljana Press; 2005.

15. Pérez P, Llana S, Alcántara E. Standard tests ability to measure impact forces reduction on mats. Int J Sports Sci Eng. 2008;2:162-8.

16. Kerwin DG, Yeadon MR, Harwood MJ. High bar release in triple somersault dismounts. J Appl Biomech. 1993;9:279-86.

17. Seele MK, Bressel EA. Comparison of upper-extremity reaction forces between the Yurchenko vault and floor exercise. J Sports Scie Med. 2005;4:85-94.

18. JcNitt-Gray L, Yokoi T, Millward C. Landing strategies used by gymnasts on different surfaces. J Appl Biomech. 1994; 10:237-52.

19. Mills MTG, Pain R, Yeadon F. Modelling a viscoelastic gymnastics landing mat during impact. J Appl Biomech. 2006;22:103-11.

58 • Rev Bras Educ Fís Esporte, (São Paulo) 2016 Jan-Mar; 30(1):51-59 
20. Piard C. Fondements de la gymnastique: technologie et pedagogie. Paris: Vigot; 1982.

21. Pozzo T, Studeny C. Théorie et pratique des sports acrobatiques. Paris: Vigot; 1987.

22. International Gymnastics Federation. Apparatus norms. Lausanne: FIG; 2015. Available from: http://www.fig-gymnastics.com/site/rules/app-norms.

23. Lüdke M, André ME. Investigação em educação: abordagens qualitativas. São Paulo: EPU; 1986.

24. Severino AJ. Metodologia do trabalho científico. São Paulo: Cortez; 1989.

25. Triviños ANS. Introdução à pesquisa em ciências sociais: a pesquisa qualitativa em educação. São Paulo: Atlas; 1992.

26. Souza Júnior MB, De Melo MST, Santiago ME. A análise de conteúdo como forma de tratamento dos dados numa pesquisa qualitativa em educação física escolar. Movimento. 2010;16:29-47.

27. Bardin L. Análise de conteúdo. Lisboa: Edições 70; 2008.

28. Chase MA, Magyar MT, Drake BM. Fear of injury in gymnastics: self-efficacy and psychological strategies to keep on tumbling. J Sport Sci. 2005;23:465-75.

29. International Gymnastics Federation. Men's artistic gymnastics: 2013-2016 Code of Points. Lausanne: FIG; 2015. Available from: http://www.fig-gymnastics.com/site/rules/disciplines/art.

\section{Acknowledgements}

This study was partially funded with resources from CNPQ (Brazilian National Research Council) and CAPES (Coordination for the Improvement of Research and Higher Education) both agencies of the Federal Government of Brazil.

ENDEREÇO

Marco Antonio Coelho Bortoleto

Departamento de Educação Física e Humanidades

Faculdade de Educação Física

Universidade Estadual de Campinas

R. Érico Veríssimo, 701 - Caixa Postal 6134 13083-970 - Campinas - SP - BRASIL

e-mail: bortoleto@fef.unicamp.br
Recebido para publicação: 03/11/2015

Aceito: 17/12/2015 